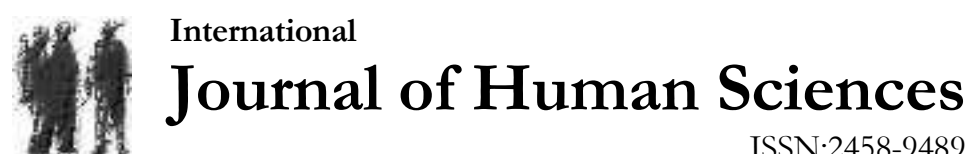

Volume 17 Issue 3 Year: 2020

\section{Anthropometric measurements of the ventrogluteal injection area: A cross-sectional study}

\author{
Emel Tuğrul ${ }^{1}$ \\ Leyla Khorshid ${ }^{2}$ \\ Özüm Tunçyürek ${ }^{3}$
}

\begin{abstract}
Research Problem / Aim: The ventrogluteal injection area is one of the areas most frequently used by nurses in intramuscular injection applications. The thicknesses of the subcutaneous tissue and the muscle tissue in this area are important for a safe injection. The aim of this study is the determination of the subcutaneous and muscle tissue thicknesses on the ventrogluteal injection area and the anthropometric data about it.

Method: The study has designed a cross-sectional study. 150 individuals who applied to the ultrasound unit of the hospital and accepted to participate in the study were included in the study. The ventrogluteal injection area was determined with the " $\mathrm{V}$ " method by the researcher. The subcutaneous and muscle tissue thicknesses from the areas on the injection area and the areas 2 and $4 \mathrm{~cm}$ around the injection area were determined using the ultrasound device. Moreover, the relation between the anthropometric measurements of the individuals (height, weight, waist, hip and crista iliaca circumferences, distance between the large trochanter and crista iliaca and crista iliaca anterior) and the tissue thicknesses on the injection area were evaluated. The data of the research were evaluated with definitive statistics, ANOVA test and posthoc Tukey test, t test and correlation analysis. The $\mathrm{p}<0.05$ value was accepted as statistically significant for all results.

Findings: The average subcutaneous tissue thickness in the injection area was determined as $15.44 \pm 8.01 \mathrm{~mm}$ and the average tissue thickness there was determined as $31.75 \pm 11.86 \mathrm{~mm}$. The subcutaneous tissue thickness in women was found more than the subcutaneous tissue thickness in men. When the tissue thicknesses 2 and $4 \mathrm{~cm}$ around the injection area were analyzed, it was found that the area where the total tissue thickness was the least was over $2 \mathrm{~cm}(41.67 \pm 14.83)$ and over $4 \mathrm{~cm}(35.79 \pm 15.55)$ of the injection area. It was determined that the average total thickness $4 \mathrm{~cm}$ around the injection area was less than $38 \mathrm{~mm}$ in underwight individuals.

Conclusions: According to the results obtained from the study, the weight and body mass index of the individual should be considered in the choice of the injection area and the length of the needle to be used when the ventrogluteal injection area was used in intramuscular injections. Especially in obese individuals, longer needles can be preferred. Besides, it must be thought that

\footnotetext{
1 Ph.D., Aydın Adnan Menderes University, Nursing Faculty, Nursing Department, emelturul@hotmail.com iD Orcid ID: 0000-0001-9046-0681

2 Prof. Dr., Ege University, Nursing Faculty, Nursing Department, emelturul@hotmail.com (D) Orcid ID: 0000-0001-7101-9014

3 Assoc. Prof. Dr., Near East University Faculty of Medicine Radilology Department Nicosia, Cyprus, ozum.tuncyurek@gmail.com

(iD) Orcid ID: 0000-0003-1669-082
} 
Tuğrul, E., Khorshıd, L., \& Tunçyürek, Ö. (2020). Anthropometric measurements of the ventrogluteal injectıon area: A cross-sectional study. Journal of Human Sciences, 17(3), 900-910. doi:10.14687/jhs.v17i3.5873

there may be the risk of bone injury $4 \mathrm{~cm}$ around the injection area in asthenic individuals and individuals with normal weight. Moreover, since the individuals' having a large waist and hip circumference is related to their subcutaneous tissue thickness, it is recommended that long needles should be chosen in these individuals.

Keywords: Intramuscular injection, nursing practise, ventrogluteal area.

\section{Introduction}

The intramuscular injection application is one of the medicine applications which are among the important functions of nurses. In intramuscular injections, the medicine passes the subcutaneous tissue and it is injected into the deep muscle tissue. The intramuscular injection should be applied on an area away from large blood vessels, nerve structures and the bone tissue (Potter \& Perry, 2013). The correct determination of the area is very important in terms of the safety of the patient and the complications to develop. The dorsogluteal and the ventrogluteal areas on the hip, the detoid muscle on the arm and the vastus lateralis and the rectus femoris muscles on the leg are used for intramuscular injections (Cocoman \& Murray, 2010; Hunter, 2008). In recent years, in the evidence about the intramuscular injection application, it is reported that the ventrogluteal injection area is the most reliable area (Cocoman \& Murray, 2010; Potter \& Perry, 2013;). The ventrogluteal injection area was used by Hochstetter in the early 1950s for the first time. The ventrogluteal injection area consists of the gluteus medius and the gluteus minimus muscles (Malkin, 2008; Nicoll \& Hesby, 2002; Potter \& Perry, 2013). In this area, the subcutaneous tissue thickness is less than the other injection areas (Hemsworth, 2000; Hunter, 2008) and the nerves and the veins are relatively less intensive. The subcutaneous fat tissue's being thin prevents giving the medicine to the fat tissue instead of the muscle tissue by mistake. Although the ventrogluteal area does not contain major nerves and blood vessels, minor nerve damages and hemorrhage because of the blood vessels in this area may occur. However, serious nerve damages do not occur in this area. In addition, the ventrogluteal area is an area which is preferred more than the dorsogluteal area because the patients can be given position easily (Cocoman \& Murray, 2010; Wyaden, Landsborough, McGowan, Baigmohamad, Finn \& Pennebaker, 2006). Moreover, it is easier to find the anatomical border points for the injection application. In the medical literature, it is reported that the muscles in the ventrogluteal area are more developed in adults and children, they can be used after seven months especially in children and the area is also a suitable area for intensive and irritating medicines (Zimmermann, 2010; Hunt, 2008). In the research made, it was also indicated that the complications such as fibrosis, nerve damage, abscess, tissue necrosis, muscle contraction, gangrene, and pain are related to the injections applied to the areas other than the ventrogluteal (VG) area (Nicoll \& Hesby, 2002; Zimmermann, 2010).

Although the medical literature recommends the ventrogluteal injection area for intramuscular injections, most nurses do not prefer this area primarily. The nurses' rates for preferring the area was reported as $17.1 \%$ (Sar1, Şahin, Yaşar, Taşkıran \& Telli, 2017), 24,8 \% (Tuğrul \& Denat, 2014) and $7.4 \%$ (Gülnar \& Çalışkan,2014). The nurses stated that their reason for not preferring the area was the difficulty of the determination of the area and the differences in the individuals' body structures making the determination of the area difficult (Donaldson \& Green, 2005; Greenway, 2014; Tuğrul \& Denat, 2014). In several studies analyzing the rates of the subcutaneous tissue and the muscle tissue of the ventrogluteal area (Larkin, Ashcroft, Elgellaie \& Hickey, 2017; Nisbet,2006), it was determined that gender and body mass index were the factors affecting a safe injection. Moreover, it was reported that waist circumference, hip circumference and the distance between the large trochanter and crista iliaca and crista iliaca anterior superior were also the factors affecting a safe injection (Kaya, Salmaslıoğlu, Terzi \& Turan, 2015; Larkin, Ashcroft, Elgellaie \& Hickey, 2017). 
Tuğrul, E., Khorshıd, L., \& Tunçyürek, Ö. (2020). Anthropometric measurements of the ventrogluteal injectıon area: A cross-sectional study. Journal of Human Sciences, 17(3), 900-910. doi:10.14687/jhs.v17i3.5873

In the intramuscular injection, long needles can be needed for the needle to pass the fat tissue and advance to the deep muscle tissue. The length of the needle should be chosen according to the weight and the fat tissue thickness of the patient (Potter \& Perry, 2013; Taylor, Lillis, LeMone \& Lynn, 2011). The patient's body mass index is a determinative factor in the fat tissue's being thick. $32 \mathrm{~mm}, 35 \mathrm{~mm}$ and $38 \mathrm{~mm}$ long needles are commonly used in intramuscular injection applications in adults. The medicine should advance at least $5 \mathrm{~mm}$ in the muscle tissue for it to be given to the deep muscle tissue. Otherwise, the medicine cannot reach the muscle tissue and it is given to the fat tissue. In the injections made with a $32 \mathrm{~mm}$ long needle, it is impossible for the needle to reach the muscle tissue if the subcutaneous tissue is $25 \mathrm{~mm}$ thick or more. When the medicine is given to the fat tissue, it is absorbed more slowly, the effect of the medicine diminishes and tissue damages may occur (Cocoman \& Murray, 2008; Wynaden, Landsborough, McGowan, Baigmohamad, Finn \& Pennebaker, 2008). In situations in which the muscle tissue and the total tissue thickness are insufficient, bone osteonecrosis and pain may develop (Cook, 2015). When $32 \mathrm{~mm}$ long needles are used, the total fat tissue and the muscle tissue thickness should be at least $35 \mathrm{~mm}$. In conclusion, the subcutaneous tissue should be thinner than $25 \mathrm{~mm}$ and the total tissue thickness should be at least $35 \mathrm{~mm}$ for safe injections. The thickness of the subcutaneous, fat and muscle tissues determine if the injection is made correctly and the medicine is injected into the fat tissue or the bone tissue in gluteal injections (Kaya, Turan \& Palloş, 2012; Nispet, 2006;). Each of the factors such as the body structure, gender, and age are directly related to the muscle tissue thickness and total tissue thickness for the intramuscular injections in individuals (Palma \& Strohfus, 2013).

Incorrect administration of ventrogluteal injections carries significant risks for the patient. In studies examining the tissue thickness in this region, only the tissue thickness at the injection point was determined. In our study, tissue thicknesses around $2 \mathrm{~cm}$ and $4 \mathrm{~cm}$ of the injection point were determined and compared with the anthropometric measurements of the individuals. In this respect, it is thought that this study will contribute to the literature.

\section{Method and Material}

The study was conducted in a cross-sectional design. The aim of this research is to obtain the subcutaneous and muscle tissue thicknesses on the ventrogluteal injection area and the anthropometric data.

\section{Participants/sample}

The research was conducted at Adnan Menderes University Research and Application Hospital Radiology Unit ultrasound department between 01.07.2015 and 01.05.2016. In the research, the calculation of the sample size was based on a study by Kaya et al (2015) in which the muscle and fat tissues in the ventrogluteal area were determined.

In the analysis performed on the study data in this study, using $G *$ Power 3.1.9.2 software at power: $0.80, \alpha=0.05$, sample size was calculated to be 145 , and using the t-test, effect size was calculated as 0.237. In our study, minimum sample size was calculated with $G *$ Power 3.1.9.2 such that effect size: $0.30, \alpha=0.05$, power: 0.80 , with the assumption that a t-test would be performed; the calculations yielded a sample size of 143 . On the basis of the convenience sample method and taking into consideration possible case losses, 150 individuals $(75$ women and 75 men) were recruited into the study. The individuals included in the study were stratified according to age (18-65 ages), body mass index $\left(18,5-40 \mathrm{~kg} / \mathrm{m}^{2}\right)$ and gender. 150 individuals, 75 women and 75 men, 50 people for each group, were included in the study according to the stratified sampling method.

\section{Criteria for Being Included in the Research}

Individuals between 18-65 ages with normal body mass index (BMI) (18.5-24.9 kg/m²), who were overweight $\left(25-29.9 \mathrm{~kg} / \mathrm{m}^{2}\right)$ and obese $\left(30-40 \mathrm{~kg} / \mathrm{m}^{2}\right)$ were included in the study. In order to determine the ventrogluteal injection area comfortably, individuals without any 
Tuğrul, E., Khorshıd, L., \& Tunçyürek, Ö. (2020). Anthropometric measurements of the ventrogluteal injection area: A cross-sectional study. Journal of Human Sciences, 17(3), 900-910. doi:10.14687/jhs.v17i3.5873

anatomical disorder were included. Since the individuals were given side-lying position while the injection area was being determined, individuals who could lie in the side-lying position were included in the scope of the research.

\section{Instruments}

The data collection form, an ultrasound device, a ruler and a tape were used in the collection of the research data. The data collection form was prepared by the researchers in accordance with the literature (Hunter, 2008, Larkin, Ashcroft, Elgellaie \& Hickey, 2017; Potter \& Perry,2013;). The data collection form consists of three parts. In the first part, there are the definitive characteristics of the individuals (age, height, weight, body mass index and gender). There is the chart where the waist and hip measurements are recorded (waist, hip and crista iliaca circumference and the distance between trochanter-crista iliaca and crista iliaca anterior superior) in the second part. There is the chart where the subcutaneous and muscle tissue thicknesses in the ventrogluteal area are recorded in the third part. The individuals' waist and hip circumference measurements were made with a tape. The subcutaneous and muscle tissue thicknesses in the ventrogluteal area were measured with a superficial ultrasound device with a $2 \mathrm{~cm}$ wide probe. The pre-application of the study was made with 20 individuals who did not participate in the sample group and accepted to participate in the application. In consequence of the preapplication, necessary corrections were made in the data collection form and the chart.

\section{Data collection}

In the data collection stage, first the introductory information of the individuals was taken and their height-weight, waist, hip and crista iliaca circumference measurements were made by a researcher. While the individuals were lying on the stretcher in the side-lying position, their clothes were taken off leaving the ventrogluteal area on their left hips naked. The researcher determined the ventrogluteal area with hands while the individual was in this position. The middle point of the triangle formed between the forefinger and the middle finger was marked with a pen (Figure 1). Points 2 and $4 \mathrm{~cm}$ right, left, above and below the middle point were determined with a ruler and these points were marked. The marking of the areas was made with a pen which would not be erased with the ultrasound gel. Then, the subcutaneous and muscle tissue thicknesses were determined from each point determined. The ultrasound probe was placed on the injection points determined by the radiology specialist with a 90 -degree angle, the needle's angle of entrance to the tissue while applying an intramuscular injection (Figure 3). The subcutaneous and muscle tissue thicknesses on each point determined were measured and recorded.

\section{Data analysis}

The analysis of the data obtained from the research was made using SPSS 18 (Statistical Package for Social Sciences) package software. Conformation to the normal dispersion in numerical variables was researched with a Shapiro - Wilk test and it was determined that the research data conformed to the normal dispersion. The data of the research were evaluated with the definitive statistics, ANOVA test and posthoc Tukey test, independent samples $t$-test, and Pearson's correlation test. The $\mathrm{p}<0.05$ value was accepted as statistically significant for all results.

\section{Ethical Approval}

Written permissions from Adnan Menderes University Faculty of Medicine Ethics Committee (No:71146310/2015-AC-CE-44) and Adnan Menderes University Research and Application Hospital were taken for the research to be conducted. Written and verbal permissions were taken from the individuals who participated in the research.

\section{Results}

A total of 150 participants, $75(50 \%)$ females and $75(50 \%)$ males, completed this study. Males are significantly taller than females, but there is no gender difference for weight and BMI. According to World Health Organization' classification of body mass index; $33.3 \%$ of participants had normal weight, $33.3 \%$ were overweight and $33.3 \%$ were obese. The individuals' 
Tuğrul, E., Khorshıd, L., \& Tunçyürek, Ö. (2020). Anthropometric measurements of the ventrogluteal injection area: A cross-sectional study. Journal of Human Sciences, 17(3), 900-910. doi:10.14687/jhs.v17i3.5873

waist circumference average is $83.1 \pm 12.3 \mathrm{~cm}$. It is $81.9 \pm 11.5 \mathrm{~cm}$ in women and $100.0 \pm 13.3 \mathrm{~cm}$ in men. The crista iliaca circumference measurement average is $95.1 \pm 12.4 \mathrm{~cm} ; 96.6 \pm 12.5 \mathrm{~cm}$ in women and $93.5 \pm 12.2 \mathrm{~cm}$ in men.

The subcutaneous tissue thickness average on the injection area was determined as $15.44 \pm 8.01 \mathrm{~mm}$ and the muscle tissue thickness was determined as $46.98 \pm 14.08 \mathrm{~mm}$. It was determined that the difference between the subcutaneous tissue thicknesses on the injection area in men and women were significant. It was determined that there was no significant difference between the muscle tissue thicknesses and the total tissue thicknesses. However, it was determined that the difference between the individuals' body mass indexes and the subcutaneous tissue, muscle tissue and total tissue thicknesses on the injection area was statistically significant. In the statistical analysis (Tukey test) conducted to find the source of the difference determined between the tissue thicknesses in the injection area and the body mass index, the difference was found to be caused by individuals with a body mass index of $30-39.8 \mathrm{~kg} / \mathrm{m}^{2}$ in the subcutaneous tissue thickness. It was found that it was caused by individuals with body mass index 18.5-24.9 $\mathrm{kg} / \mathrm{m}^{2}$ and $25-29.9 \mathrm{~kg} / \mathrm{m}^{2}$ in thickness of muscle tissue. The source of the difference in total tissue thickness was determined to originate from all groups (Table 1).

Table 1. Dispersion of the subcutaneous tissue, muscle tissue and total tissue thicknesses according to gender and body mass index

\begin{tabular}{|l|c|c|c|}
\hline \multirow{3}{*}{ Gender } & $\begin{array}{c}\text { S.C. tissue thickness } \\
(\mathrm{mm})\end{array}$ & $\begin{array}{c}\text { Muscle tissue thickness } \\
(\mathrm{mm})\end{array}$ & $\begin{array}{c}\text { Total tissue thickness } \\
(\mathrm{mm})\end{array}$ \\
\cline { 2 - 4 } & Mean $\pm \mathrm{SD}$ & Mean $\pm \mathrm{SD}$ & Mean $\pm \mathrm{SD}$ \\
\hline \multirow{2}{*}{$\begin{array}{l}\text { Female } \\
\text { Male }\end{array}$} & $17.04 \pm 8.20$ & $30.22 \pm 12.30$ & $47.26 \pm 15.02$ \\
\cline { 2 - 4 } & $13.85 \pm 7.54$ & $32.84 \pm 11.33$ & $46.69 \pm 13.18$ \\
\hline BMI $\left(\mathrm{kg} / \mathrm{m}^{2}\right)$ & $\mathrm{t}=2.47 \mathrm{p}=\mathbf{0 . 0 0}$ & $\mathrm{t}=-1.35 \mathrm{p}=0.178$ & $\mathrm{t}=0.248 \mathrm{p}=0.140$ \\
\hline $\begin{array}{l}\text { 18.5-24.9 } \\
25-29.9^{\mathrm{b}}\end{array}$ & $12.31 \pm 6.02$ & $28.25 \pm 11.98^{*}$ & $40.57 \pm 13.56^{*}$ \\
\cline { 2 - 4 } $30-39.8^{\mathrm{c}}$ & $13.34 \pm 6.06$ & $34.02 \pm 11.47^{*}$ & $47.36 \pm 11.98^{*}$ \\
\cline { 2 - 4 } & $20.68 \pm 8.94^{*}$ & $32.32 \pm 11.60$ & $53.01 \pm 14.02^{*}$ \\
\cline { 2 - 5 } & $\mathrm{F}=20.45 \quad \mathrm{p}=\mathbf{0 . 0 0}$ & $\mathrm{F}=3.22 \quad \mathrm{p}=\mathbf{0 . 0 0}$ & $\mathrm{F}=11.09 \quad \mathrm{p}=\mathbf{0 . 0 0}$ \\
\hline Difference & $\mathrm{c}$ & $\mathrm{a}, \mathrm{b}$ & $\mathrm{a}, \mathrm{b}, \mathrm{c}$ \\
\hline
\end{tabular}

SD: Standart Deviation, t: independent samples $t$-test, F: ANOVA test, *Posthoc Tukey test

In the study, the relationship between subcutaneous tissue thickness, muscle tissue thickness, total tissue thickness, age, trochanter - cras distance, trochanter - crista lliaca distance, and height, weight, waist, hip and crista iliaca circumference at the ventrogluteal injection site were examined. Accordingly, it was determined that there was a moderate positive correlation between the thickness of the subcutaneous tissue and the circumference of the weight, waist, hip and crista iliaca. It has been determined that there is a weak correlation between total tissue thickness and the length of weight, waist, hip and crista iliaca circumference. It was determined that there was a weak relationship between height, weight and there was a positive weak relationship between the distance trochanter-cias and trochanter crista iliaka and height, weight and hip circumference (Table 2). 
Tuğrul, E., Khorshıd, L., \& Tunçyürek, Ö. (2020). Anthropometric measurements of the ventrogluteal injection area: A cross-sectional study. Journal of Human Sciences, 17(3), 900-910. doi:10.14687/jhs.v17i3.5873

Table 2. Pearson's correlation between the tissue thicknesses on the ventrogluteal injection area and age, height, weight, waist and hip circumference measurements

\begin{tabular}{|l|l|c|c|c|c|}
\hline Measurements & Height $(\mathrm{cm})$ & Weight $(\mathrm{kg})$ & $\begin{array}{c}\text { Waist } \\
\text { circumference }\end{array}$ & $\begin{array}{l}\text { Hip } \\
\text { circumferenc }\end{array}$ & $\begin{array}{c}\text { Crista iliaca } \\
\text { circumference }\end{array}$ \\
\cline { 2 - 6 } & $\mathrm{r} / \mathrm{p}$ & $\mathrm{r} / \mathrm{p}$ & $\mathrm{r} / \mathrm{p}$ & $\mathrm{r} / \mathrm{p}$ & $\mathrm{r} / \mathrm{p}$ \\
\hline $\begin{array}{l}\text { S.C. Tissue } \\
\text { Thickness }\end{array}$ & $-0.096 / 0.242$ & $0.414^{* *} / \mathbf{0 . 0 0 0}$ & $0.412^{* *} / \mathbf{0 . 0 0 0}$ & $0.533^{* *} / \mathbf{0 . 0 0 0}$ & $0.463^{* *} / \mathbf{0 . 0 0 0}$ \\
\hline $\begin{array}{l}\text { Muscle Tissue } \\
\text { Thickness }\end{array}$ & $0.018 / 0.826$ & $0.089 / 0.280$ & $0.041 / 0.620$ & $-0.040 / 0.626$ & $-0.031 / 0.707$ \\
\hline $\begin{array}{l}\text { Total Tissue } \\
\text { Thickness }\end{array}$ & $-0.039 / 0.632$ & $0.310^{* *} / \mathbf{0 . 0 0 0}$ & $0.269^{* *} / \mathbf{0 . 0 0 1}$ & $0.270^{* *} / \mathbf{0 . 0 0 1}$ & $0.238^{* *} / \mathbf{0 . 0 0 3}$ \\
\hline Age & $-0.298^{* *} / \mathbf{0 . 0 0 0}$ & $-0.012 / 0.883$ & $0.150 / 0.068$ & $0.080 / 0.330$ & $0.161^{*} / 0.049$ \\
\hline $\begin{array}{l}\text { Trochanter - } \\
\text { CIAS Distance } \\
\text { (cm) }\end{array}$ & $0.324^{* *} / \mathbf{0 . 0 0 0}$ & $0.261^{* *} / \mathbf{0 . 0 0 1}$ & $0.121 / 0.141$ & $0.251^{* *} / \mathbf{0 . 0 0 2}$ & $0.090 / 0.271$ \\
\hline $\begin{array}{l}\text { Trochanter- } \\
\text { Crista Iliaca } \\
\text { Distance (cm) }\end{array}$ & $0.341^{* *} / \mathbf{0 . 0 0 0}$ & $0.258^{* *} / \mathbf{0 . 0 0 1}$ & $0.107 / 0.194$ & $0.240^{* *} / \mathbf{0 . 0 0 3}$ & $0.078 / 0.345$ \\
\hline
\end{tabular}

r: Pearson's correlation value, ${ }^{* *} \mathrm{p}<0,05$

In the study, subcutaneous and muscle tissue thicknesses of the ventrogluteal injection site around $2 \mathrm{~cm}$ and $4 \mathrm{~cm}$ were measured. The average of tissue thicknesses in these regions are given in table 3. According to this; It was determined that the place where the average of subcutaneous tissue, muscle tissue and total tissue thickness was the thinnest was $4 \mathrm{~cm}$ above the injection site and the thickest was. $4 \mathrm{~cm}$ right the injection site (Table 3).

Table 3. The subcutaneous and muscle tissue thicknesses $2 \mathrm{~cm}$ and $4 \mathrm{~cm}$ around the ventrogluteal injection area

\begin{tabular}{|c|c|c|c|}
\hline \multirow{2}{*}{$\begin{array}{l}2 \mathrm{~cm} \text { around the Injection } \\
\text { Area }\end{array}$} & $\begin{array}{l}\text { Subcutaneous } \\
\text { Tissue } \\
\text { Thicknesses } \\
\text { (mm) }\end{array}$ & $\begin{array}{l}\text { Muscle Tissue } \\
\text { Thicknesses } \\
(\mathrm{mm})\end{array}$ & $\begin{array}{c}\text { Total Tissue } \\
\text { Thicknesses } \\
\text { (mm) }\end{array}$ \\
\hline & Mean \pm SD & Mean \pm SD & Mean \pm SD \\
\hline $2 \mathrm{~cm}$ Above & $13.70 \pm 7.20$ & $27.97 \pm 12.06$ & $41.67 \pm 14.83$ \\
\hline $2 \mathrm{~cm}$ Below & $16.40 \pm 8.21$ & $29.61 \pm 12.29$ & $46.01 \pm 14.29$ \\
\hline $2 \mathrm{~cm}$ Right & $17.03 \pm 8.14$ & $32.71 \pm 11.92$ & $49.74 \pm 14.12$ \\
\hline $2 \mathrm{~cm} \mathrm{Left}$ & $14.34 \pm 7.81$ & $30.91 \pm 12.63$ & $45.26 \pm 14.85$ \\
\hline \multicolumn{4}{|l|}{$\begin{array}{l}4 \mathrm{~cm} \text { around the Injection } \\
\text { Area }\end{array}$} \\
\hline $4 \mathrm{~cm}$ Above & $11.94 \pm 6.57$ & $23.85 \pm 12.39$ & $35.79 \pm 15.55$ \\
\hline $4 \mathrm{~cm}$ Below & $16.73 \pm 8.34$ & $26.68 \pm 12.40$ & $43.41 \pm 13.86$ \\
\hline $4 \mathrm{~cm}$ Right & $17.90 \pm 8.78$ & $33.47 \pm 12.29$ & $51.37 \pm 13.77$ \\
\hline $4 \mathrm{~cm} \mathrm{Left}$ & $13.15 \pm 7.38$ & $29.28 \pm 13.56$ & $42.43 \pm 15.58$ \\
\hline
\end{tabular}

SD: Standart Deviation 
Tuğrul, E., Khorshıd, L., \& Tunçyürek, Ö. (2020). Anthropometric measurements of the ventrogluteal injection area: A cross-sectional study. Journal of Human Sciences, 17(3), 900-910. doi:10.14687/ihs.v17i3.5873

According to the findings obtained, while the tissue thicknesses were the least $2 \mathrm{~cm}$ around the injection area in the individuals whose body mass indexes were between $18.5-24.9 \mathrm{~kg} / \mathrm{m}^{2}$, the tissue thicknesses were found the highest in the individuals whose body mass indexes were between $30-40 \mathrm{~kg} / \mathrm{m}^{2}$. It was determined that the area where the total tissue thickness was the lowest was 2 $\mathrm{cm}$ above the injection area in individuals with body mass index between $18.5-24.9 \mathrm{~kg} / \mathrm{m}^{2}$ The area where the total tissue thickness was the highest was determined as $2 \mathrm{~cm}$ right of the injection area in the individuals with body mass index between $30-40 \mathrm{~kg} / \mathrm{m}^{2}$. It was determined that the difference between the subcutaneous tissue thickness averages was statistically significant $2 \mathrm{~cm}$ around the injection area according to the body mass index. According to the statistical analysis (Tukey test) to determine which group this difference originated from, the difference between the tissue thicknesses above $2 \mathrm{~cm}$ of the injection point and the body mass index was determined from all groups. It was determined that the difference between the tissue thickness and body mass index $2 \mathrm{~cm}$ below the injection point, to the right and left of the injection point originated from the group with a body mass index of $18.5-24.9 \mathrm{~kg} / \mathrm{m}^{2}$ (Table 4).

Table 4. Total Tissue Thickness Averages of the Points Determined Around $2 \mathrm{Cm}$ of the Injection Point and the Body Mass Index Averages of the Individuals.

\begin{tabular}{|c|c|c|c|c|}
\hline \multirow[b]{2}{*}{$\mathrm{BKI} \mathrm{kg} / \mathrm{m}^{2}$} & \multicolumn{4}{|c|}{ Total Tissue Thicknesses (mm) } \\
\hline & $\begin{array}{l}2 \mathrm{~cm} \text { above the } \\
\text { injection point }\end{array}$ & $\begin{array}{l}2 \mathrm{~cm} \text { below the } \\
\text { injection point }\end{array}$ & $\begin{array}{l}2 \mathrm{~cm} \text { right of the } \\
\text { injection point }\end{array}$ & $\begin{array}{l}2 \mathrm{~cm} \text { left of the } \\
\text { injection point }\end{array}$ \\
\hline & Mean \pm SD & Mean \pm SD & Mean \pm SD & Mean \pm SD \\
\hline $18.5-24.9^{a}$ & $35.13 \pm 11.65^{*}$ & $40.76 \pm 12.45^{*}$ & $44.00 \pm 12.53 *$ & $38.19 \pm 12.84 *$ \\
\hline $25-29.9^{b}$ & $42.96 \pm 9.78^{*}$ & $48.68 \pm 12.43$ & $51.97 \pm 11.94$ & $47.24 \pm 14.48$ \\
\hline $30-39.8^{c}$ & $49.16 \pm 13.72 *$ & $53.48 \pm 13.17$ & $54.48 \pm 14.24$ & $51.14 \pm 14.48$ \\
\hline & $\begin{array}{c}F=17.67 \\
\mathrm{p}=\mathbf{0 . 0 0}\end{array}$ & $\begin{array}{c}\mathrm{F}=12.80 \\
\mathrm{p}=\mathbf{0 . 0 0}\end{array}$ & $\begin{array}{l}F=8.92 \\
p=0.00\end{array}$ & $\begin{array}{c}F=11.32 \\
\mathrm{p}=\mathbf{0 . 0 0}\end{array}$ \\
\hline Difference & $a, b, c$ & $\mathrm{a}$ & $\mathrm{a}$ & $\mathrm{a}$ \\
\hline
\end{tabular}

F: ANOVA test, *Posthoc Tukey test

Whether there was a difference between the total tissue thicknesses $4 \mathrm{~cm}$ around the ventrogluteal injection area and the body masses of the individuals was analyzed. According to this, it was determined that the area where the tissue thickness was the least in the individuals with body mass index between $18.5-24.9 \mathrm{~kg} / \mathrm{m}^{2}$ was $4 \mathrm{~cm}$ above the injection point and the area where it was the thickest was $4 \mathrm{~cm}$ right of the injection point in individuals with body mass index between 30 $40 \mathrm{~kg} / \mathrm{m}^{2}$. It was determined that the difference between the individuals' body mass indexes and the total tissue thicknesses $4 \mathrm{~cm}$ around the injection area was statistically significant. According to the statistical analysis (Tukey test) to determine which group this difference originated from, the difference between the tissue thicknesses above $4 \mathrm{~cm}$ of the injection point and the body mass index was determined from all groups. It was determined that the difference between the tissue thickness and body mass index $4 \mathrm{~cm}$ below the injection point, to the right and left of the injection point originated from the group with a body mass index of 18.5-24.9 (Table 5). 
Tuğrul, E., Khorshıd, L., \& Tunçyürek, Ö. (2020). Anthropometric measurements of the ventrogluteal injection area: A cross-sectional study. Journal of Human Sciences, 17(3), 900-910. doi:10.14687/jhs.v17i3.5873

Table 5. Total Tissue Thickness Means Around $4 \mathrm{Cm}$ of Injection Point and Body Mass Index Averages of Individuals.

\begin{tabular}{|l|c|c|c|c|}
\hline \multirow{2}{*}{ BKI kg/m } & \multicolumn{4}{|c|}{ Total Tissue Thicknesses (mm) } \\
\cline { 2 - 5 } & $\begin{array}{c}4 \mathrm{~cm} \text { above the } \\
\text { injection point }\end{array}$ & $\begin{array}{c}4 \mathrm{~cm} \text { below the } \\
\text { injection point }\end{array}$ & $\begin{array}{c}4 \mathrm{~cm} \text { right of the } \\
\text { injection point }\end{array}$ & $\begin{array}{l}4 \mathrm{~cm} \text { left of the } \\
\text { injection point }\end{array}$ \\
\hline $18.5-24.9^{\mathrm{a}}$ & Mean \pm SD & Mean \pm SD & Mean \pm SD & Mean \pm SD \\
\hline $25-29.9^{\mathrm{b}}$ & $36.59 \pm 12.77^{*}$ & $39.40 \pm 10.82^{*}$ & $45.24 \pm 11.66^{*}$ & $36.35 \pm 13.69^{*}$ \\
\hline $30-39.8^{\mathrm{c}}$ & $43.90 \pm 14.74^{*}$ & $46.26 \pm 13.69$ & $53.60 \pm 12.18$ & $44.35 \pm 14.02$ \\
\hline & $\begin{array}{c}\mathrm{F}=18.43 \\
\mathrm{p}=\mathbf{0 . 0 0}\end{array}$ & $\begin{array}{c}\mathrm{F}=10.00 \\
\mathrm{p}=\mathbf{0 . 0 0}\end{array}$ & $\begin{array}{c}\mathrm{F}=8.55 \\
\mathrm{p}=\mathbf{0 . 0 0}\end{array}$ & $\begin{array}{c}\mathrm{F}=9.23 \\
\mathrm{p}=\mathbf{0 . 0 0}\end{array}$ \\
\hline Difference & $\mathrm{a}, \mathrm{b}, \mathrm{c}$ & $\mathrm{a}$ & $\mathrm{a}$ & $\mathrm{a}$ \\
\hline
\end{tabular}

F: ANOVA test, *Posthoc Tukey test

\section{Discussion}

Total 150 people, 75 women and 75 men, were included in the study. It was determined that the subcutaneous tissue in women was thicker than the subcutaneous tissue in men. Similar results are seen in the literature (Burbridge, 2007; Kaya, Salmaslığlu, Terzi, Turan \& Acunas, 2015; Larkin, Ashcroft, Elgellaie \& Hickey, 2017; Nisbet, 2006). In the study conducted by Kaya et. al (2014), it was determined that the injections were made on the subcutaneous tissue on the dorsogluteal and ventrogluteal areas in $18 \%$ of the women and this rate was $1.5 \%$ in men. However, it was determined that the muscle tissue and the total tissue thickness did not differ according to gender. Although the subcutaneous tissue thickness is higher in women in our study too, it was determined that there was no difference in men and women between the muscle tissue thickness and total tissue thicknesses.

The subcutaneous tissue's being thick is a situation which prevents to make injections into the muscles (Palma \& Strokfus, 2013). The needle should pass the subcutaneous tissue and advance for at least $3 \mathrm{~mm}$ in the muscle tissue for the medicine to be given into the muscle tissue. In this situation, the length of the needle can differ according to the subcutaneous tissue thickness of the individuals in intramuscular injections. In our study, it was determined that the difference in subcutaneous tissue thickness according to body mass index was caused by individuals with a body mass index of $30-39.8 \mathrm{~kg} / \mathrm{m}^{2}$. In these individuals, the thickening of the subcutaneous tissue may be a condition that prevents the drug to be given to the muscle tissue during intramuscular injections. In the study they conducted, Larkin et. al (2017) have reported that the subcutaneous tissue thickness should be less than $25 \mathrm{~mm}$ when $32 \mathrm{~mm}$ long needles are used in injections. In our study, the subcutaneous tissue thickness was found more than $25 \mathrm{~mm}$ or nearly $25 \mathrm{~mm}$ in 6 individuals. It was determined that the body mass index of these individuals was between 24.5 and $31.6 \mathrm{~kg} / \mathrm{m}^{2}$ and 5 of them were female and 1 of them was male. Bayea and Nicoll (1995) observed the intramuscular injections made in 15 women in their studies. They reported that the medicine stayed in the subcutaneous tissue in the individuals whose subcutaneous tissue thickness was high on the dorsogluteal and ventrogluteal areas with $32 \mathrm{~mm}$ needles and $38 \mathrm{~mm}$ needles should be used. They remarked that $51 \mathrm{~mm}$ ( 2 inches) long needles should be recommended in obese individuals whose subcutaneous tissue thickness was high but since these needles increased the pain, one should be careful while using them. In our study, the subcutaneous tissue thickness average was found $20.68 \pm 8.94 \mathrm{~mm}$ and the total tissue thickness average was found $53.01 \pm 14.02$ $\mathrm{mm}$ in the individuals with body mass index between $37.01-39.8 \mathrm{~kg} / \mathrm{m}^{2}$. The subcutaneous tissue thickness average was found $36.06 \pm 7.96 \mathrm{~mm}$ in 5 individuals with body mass index between 37.01 $-39.8 \mathrm{~kg} / \mathrm{m}^{2}$. It is impossible to give the medicine to the muscle tissue when $38 \mathrm{~mm}$ long needles 
Tuğrul, E., Khorshıd, L., \& Tunçyürek, Ö. (2020). Anthropometric measurements of the ventrogluteal injectıon area: A cross-sectional study. Journal of Human Sciences, 17(3), 900-910. doi:10.14687/jhs.v17i3.5873

are used in these individuals. Similar results were obtained also in the studies conducted by Nispet, Kaya and Larkin et al.Damage of the bone tissue is a complication as serious as giving the medicine to the subcutaneous tissue in intramuscular injections (Wyaden, Landsborough, McGowan, Baigmohamad, Finn \& Pennebaker, 2006). In ventrogluteal injections, the injection area's being small may require turning to another injection area for the repeating injections. There should be at least $2 \mathrm{~cm}$ difference between the needle's points of entering the tissue in each injection. In our study, the tissue thicknesses 2 and $4 \mathrm{~cm}$ around the ventrogluteal injection area were also analyzed.

When the total tissue thicknesses $2 \mathrm{~cm}$ around the injection area were analyzed, it was seen that the total tissue thickness $2 \mathrm{~cm}$ above the injection area was $35.13 \pm 11.65 \mathrm{~mm}$ in body mass index between $18.5-24.9 \mathrm{~kg} / \mathrm{m}^{2}$ individuals and it was $42.96 \pm 9.78 \mathrm{~mm}$ in individuals with normal weight. According to these results, the risk of bone damage increases when the injection was applied with $38 \mathrm{~mm}$ long needles $2 \mathrm{~cm}$ above the injection area in cachectic individuals. If it is thought that the needle should advance for $3 \mathrm{~mm}$ in the muscle tissue in the individuals with normal weight, it can be said that the total tissue thickness is liminal. $32 \mathrm{~mm}$ long needles can be used while making injection $2 \mathrm{~cm}$ above the injection area in these individuals.

When the tissue thicknesses $4 \mathrm{~cm}$ around the injection area were analyzed, the total tissue thickness was found $27.59 \pm 12.77 \mathrm{~mm} 4 \mathrm{~cm}$ above the injection area in body mass index between $18.5-24.9 \mathrm{~kg} / \mathrm{m}^{2}$ individuals. It was found $39.40 \pm 10.824 \mathrm{~cm}$ below the injection area and $36.35 \pm 13.69 \mathrm{~mm} 4 \mathrm{~cm}$ left of the area. The total tissue thickness was found $36.34 \pm 12.84 \mathrm{~mm} 4 \mathrm{~cm}$ above the injection area in the individuals who had normal weight. We can say that the possibility of bone damage is high or liminal in injections made with $38 \mathrm{~mm}$ long needles from these areas. Although the body mass index is important in terms of applying the injection into the subcutaneous tissue or the bone structures, the anthropometric structures of the individuals are also important in terms of injections (Larkin, Ashcroft, Elgellaie \& Hickey, 2017). In our study, it was determined that the waist circumference, hip circumference, crista iliaca circumference and the subcutaneous tissue thickness were related. The subcutaneous tissue thickness increases in the individuals as their waist, hip, and crista iliaca circumference increases. Larkin et al compared the individuals' waist and hip circumferences and body mass indexes and tissue thicknesses and formed an algorithm for ventrogluteal injection. In this algorithm, injection is not recommended for individuals under 65 kilograms, whose body mass index is below 25 and waist circumference is 75 $\mathrm{cm}$ and below because of bone damage risk. When the same criteria were considered in our study, the total tissue thickness average in 17 individuals in these criteria was found $38 \pm 13,6 \mathrm{~mm}$. According to this result, a result similar to the study conducted by Larkin et al was found in our study. A correlation on the positive direction was found between height and weight and the Trochanter-CIAS distance and Trochanter-crista iliaca distance. However, no correlation was determined between the subcutaneous tissue thickness and the muscle tissue thickness.

\section{Conclusions and Recommendations}

According to the results obtained from the study, the individuals' weight and body mass index should be considered in the selection of the injection area and the length of the needles to be used while the ventrogluteal injection area is being used in intramuscular injections. Longer needles may be preferred especially in obese individuals. Besides, it should be thought that bone damage can occur $4 \mathrm{~cm}$ around the injection area in cachectic individuals and individuals with normal weight in repeating injections. Moreover, since the individuals' waist and hip circumferences' being high is also related to the subcutaneous tissue thickness, long needles also should be preferred in needle selection in these individuals.

\section{Previous presentations}

This study was conducted a PhD project submitted to the Ege University Health Sciences Institute. The authors express their gratitude to all the participants. This study was presented in $1 \mathrm{st}$ International Health Science and Life Congress, 02-05 May 2018, Burdur, Turkey. 
Tuğrul, E., Khorshıd, L., \& Tunçyürek, Ö. (2020). Anthropometric measurements of the ventrogluteal injection area: A cross-sectional study. Journal of Human Sciences, 17(3), 900-910. doi:10.14687/jhs.v17i3.5873

\section{References}

Burbridge, B.E. (2007). Computed tomographic measurement of gluteal subcutane-ous fat thickness in reference to failure of gluteal intramuscular injections. Can. Assoc. Radiol. J., 58 (2), 72-75.

Cocoman, A. \& Murray, J. (2006). IM injections: how's your technique. World Ir. Nurs, 14(4), 50-51.

Cook, I.F. (2015). Best vaccination practice and medically attended injection site events following deltoid intramuscular injection. Hum. Vaccin Immunother, 11 (5), 1184-1191. doi:10.1080/21645515.2015.1017694

Donaldson, C. \& Green, J. (2005). Using the ventrologluteal site for intramuscular injection. Nurs. Times, 101 (16), 36-38.

Greenway, K. (2014). Rituals in nursing: intramuscular injections. J. Clin. Nurs, 23, 3583-3588. doi: 10.1111 /jocn.12627

Hemsworth, S. (2000). İntramuscular (IM) İnjection Technique. Pediatric Nursing, 12(9), 17- 20. doi: 10.7748/paed2000.11.12.9.17.c672

Hunt, C.W. (2008). Which site is best for an I.M. injection? Nursing, 38,62. doi: 10.1097/01.NURSE. 0000341089.14071.1e

Hunter, J. (2008). Intramuscular injection techniques. Nurs. Stand, 22 (24), 35-40. doi: 10.7748/ ns2008.02.22.24.35.c6413

Gülnar, E., \& Özveren, H. (2016). An evaluation of the effectiveness of a planned training program for nurses on administering intramuscular injections into the ventrogluteal site. Nurse Educ. Today, 36, 360-363. doi: 10. 1016/ j.nedt.2015.09.001

Kaya, N., Salmaslıoğlu, A., Terzi, B., Turan, N., \& Acunas, B. (2015). The reliability of site determination methods in ventrogluteal area injection: a cross-sectional study. Int. J. Nurs. Stud, 52 (1), 355-360. doi: 10. 1016/ j.ijnurstu.2014.07.002

Kaya, N., Turan, N., \& Palloş, A.Ö. (2012). Shouldn't the dorsogluteal area be used for intramuscular injection? Istanbul University Florence Nightingale Journal of Nursing, 20 (2), 146153.

Larkin,T.A., Ashcroft, E., Elgellaie, A., \& Hickey, B.A. (2017). Ventrogluteal versus dorsogluteal site selection: A cross-sectional study of muscle and subcutaneous fat thicknesses and an algorithm incorporating demographic and anthropometric data to predict injection outcome. Int J Nurs Stud., 71,1-7. doi:10.1016/j.ijnurstu.2017.02.017

Malkin, B. (2008). Are techniques used for intramuscular injection based on research evidence? Nurs. Times, 104, 48-51.

Nicoll, L.H., \& Hesby, A. (2002). Intramuscular injection: an integrative research review and guideline for evidence-based practice. Appl. Nurs. Res, 15 (3), 149-162. doi: 10.1053/ apnr.2002.34142

Nisbet, A.C. (2006). Intramuscular gluteal injections in the increasingly obese population: retrospective study. Br. Med. J, 332 (7452), 637-638. doi: 10.1136/ bmj.38706.742731.47

Palma, S., \& Strohfus, P. (2013). Are IM injections IM in obese and overweight females? A study in injection technique. Appl. Nurs. Res, 26, 1-4. doi: 10.1016/ j.apnr.2013.09.002

Potter, P.A, \& Perry, A.G. (2013). Fundamentals of Nursing, 7th ed. Mosby Year Book, Philadelphia.

Sarı, D., Şahin, M., Yaşar, E., Taşkıran, N., \& Telli,S. (2017). Investigation of Turkish nurses frequency and knowledge of administration of intramuscular injections to the ventrogluteal site: Results from questionnaires. Nurse Educ Today, 56,47-51. doi: 10.1016/ j.nedt.2017.06.005

Taylor, C., Lillis, C., LeMone, P., \& Lynn, P. (2011). Fundamentals of Nursing the Art and Science of Nursing Care. Seventh ed. Wolters Kluwer, Lippincott Williams \& Wilkins, China.

Tuğrul, E., \& Denat, Y. (2014). Information, Opinions and Practices of Nurses on Injection Application in Ventrogluteal Area. Dokuz Eylül University Nursing Faculty e-Journal,7 (4), 275284. 
Tuğrul, E., Khorshıd, L., \& Tunçyürek, Ö. (2020). Anthropometric measurements of the ventrogluteal injectıon area: A cross-sectional study. Journal of Human Sciences, 17(3), 900-910. doi:10.14687/jhs.v17i3.5873

Wynaden, D., Landsborough, I., McGowan, S., Baigmohamad, Z., Finn, M., \& Pennebaker, D. (2006). Best practice guidelines for the administration of intramuscular injections in the mental health setting. Int. J. Ment. Health Nurs., 15 (3), 195-200. doi: 10.1111/j.14470349.2006.00423

Zimmermann, P.G. (2010). Revisiting IM injections: The ventrogluteal site is the safest for intramuscular injection Am. J. Nurs., 110 (2), 661.doi:10.1097/01.NAJ.0000368058.72729.c6

\section{Appendixs}

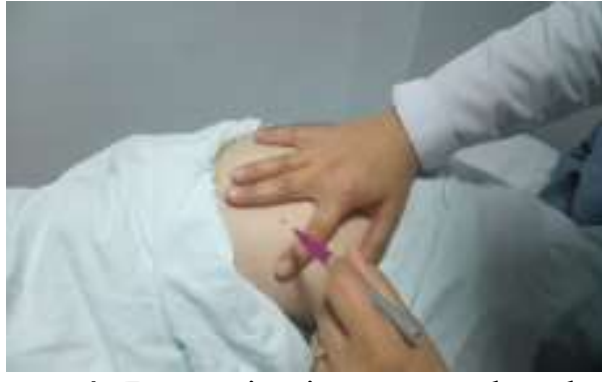

Figure 1. Determination ventrogluteal area point. ventrogluteal injection point.

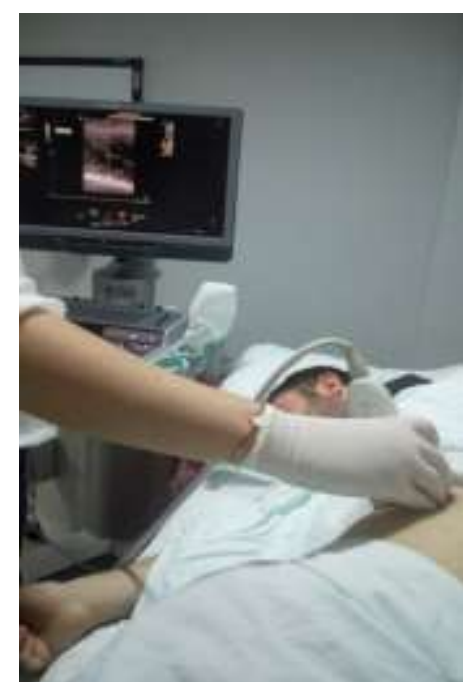

Figure 3. Ultrason probe placed on injection points.

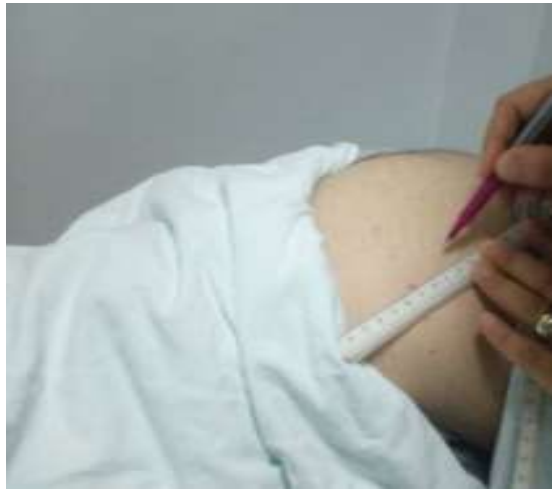

Figure 2. Points around 2 and $4 \mathrm{~cm}$

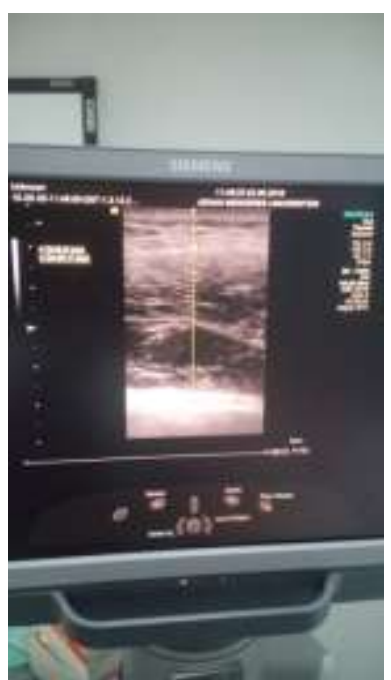

Figure 4. Subcutaneous and muscle tissue thicknesses. 